\title{
Transcriptional regulation, occurrence and putative role of the Pht family of Streptococcus pneumoniae
}

Correspondence

Jan T. Poolman

jan.poolman@gskbio.com

Received 1 June 2010

Revised 14 October 2010

Accepted 18 October 2010
Stéphane Rioux, ${ }^{1}$ Cécile Neyt, ${ }^{1}$ Emmanuel Di Paolo, ${ }^{1}$ Laurence Turpin, ${ }^{1}$ Nathalie Charland, ${ }^{2}$ Steve Labbé, ${ }^{3}$ Marie-Cécile Mortier, ${ }^{1}$ Tim J. Mitchell, ${ }^{4}$ Christiane Feron, ${ }^{1}$ Denis Martin ${ }^{3}$ and Jan T. Poolman ${ }^{1}$

\author{
${ }^{1}$ GSK Biologicals, Rixensart, Belgium \\ ${ }^{2}$ Medicago Inc., Québec, Québec, Canada \\ ${ }^{3}$ GSK Biologicals, Laval, Québec, Canada \\ ${ }^{4}$ University of Glasgow, Glasgow, UK
}

\begin{abstract}
Restricted to the genus Streptococcus, the Pht protein family comprises four members: PhtA, PhtB, PhtD and PhtE. This family has the potential to provide a protein candidate for incorporation in pneumococcal vaccines. Based on sequence analysis and on RT-PCR experiments, we show here that the pht genes are organized in tandem but that their expression, except that of phtD, is monocistronic. PhtD, PhtE, PhtB and PhtA are present in 100, 97, 81 and $62 \%$ of the strains, respectively, and, by analysing its sequence conservation across 107 pneumococcal strains, we showed that PhtD displays very little variability. To analyse the physiological function of these proteins, several mutants were constructed. The quadruple Pht-deficient mutant was not able to grow in a poor culture medium, but the addition of $\mathrm{Zn}^{2+}$ or $\mathrm{Mn}^{2+}$ restored its growth capacity. Moreover, the phtD mRNA expression level increased when the culture medium was depleted in zinc. Therefore, we suggest that these proteins are zinc and manganese scavengers, and are able to store these metals and to release them when the bacterium faces an ion-restricted environment. The data also showed that this protein family, and more particularly PhtD, is a promising candidate to be incorporated into pneumococcal vaccines.
\end{abstract}

\section{INTRODUCTION}

Streptococcus pneumoniae is one of the leading causes of infectious morbidity and mortality, responsible for a large spectrum of infections such as otitis media, pneumonia, bacteraemia and meningitis (Hausdorff et al., 2005; McCullers \& Tuomanen, 2001). The emergence of antibiotic-resistant strains of this micro-organism has further underlined the need for providing effective prophylactic vaccination (Bridy-Pappas et al., 2005; Lynch \& Zhanel, 2005).

Current vaccines comprise epidemiologically dominant serotype-based selections of pneumococcal capsular polysaccharides, conjugated or not to a carrier protein (Dagan et al., 2004; Fedson \& Musher, 2004; Mbelle et al., 1999; Smart et al., 1987). However, the vaccine formulations do not cover all serotypes of $S$. pneumoniae, which might be of particular relevance in certain regions that have different

Abbreviations: 5'-RACE, 5'-rapid amplification of cDNA ends; CDC, Centers for Disease Control \& Prevention; MLST, multi-locus sequence type; PMEN, pneumococcal molecular epidemiology network; ST, sequence type; TPEN, $N, N, N^{\prime}, N^{\prime}$-tetrakis(2-pyridylmethyl) ethylenediamine. dominant serotypes (Dagan et al., 1992). In addition, one may expect that the use of serotype-specific vaccines could allow the positive selection of non-vaccine serotypes (Nunes et al., 2008; Singleton et al., 2007).

An alternative approach involves the development of vaccines that target common pneumococcal antigens. Among multiple candidates, the Pht protein family, restricted to the genus Streptococcus, is promising, as it is well conserved across pneumococcal species (Hamel et al., 2004; Zhang et al., 2001), and its members are immune targets in infected individuals and protective antigens in immunized mice upon challenge (Beghetto et al., 2006). Originally, this protein family was independently reported by three groups, and three separate denominations were used: Pht (for pneumococcal histidine triad) (Adamou et al., 2001), Php (for pneumococcal histidine protein) (Zhang et al., 2001) and BVH (Hamel et al., 2004). Those proteins are characterized by a histidine triad motif, $\mathrm{HxxHxH}$, repeated five to six times in their amino acid sequences. Four members of this family have been described: PhtA (BVH-113), PhtB (PhpA/BVH-11) and PhtD (BVH-11-2), which share up to $81 \%$ sequence identity, and PhtE (BVH-3), which is divergent from the three other proteins, showing 
only up to $35 \%$ sequence identity with them. PhtE is a longer protein, the only one with six repeats of the histidine triad motif. In mouse immunization studies, all members of the Pht family have been shown to afford a high level of protection to subsequent pneumococcal challenge with a number of different strains/serotypes (Adamou et al., 2001; Godfroid et al., 2011; Hamel et al., 2004; Ogunniyi et al., 2007; Wizemann et al., 2001; Zhang et al., 2001).

Despite their potential importance in vaccination against $S$. pneumoniae infection, the biological function of these proteins has yet to be determined. Results from antibodylabelling and flow cytometry experiments demonstrated that the Pht proteins are exposed on the surface of the encapsulated bacterium (Hamel et al., 2004), which is in agreement with their relevance as vaccine targets. Based on signature-tagged mutagenesis, it has been suggested that PhtA, PhtB and PhtD are involved in lung-specific virulence (Hava \& Camilli, 2002), without further indication about their biological function. Among their putative roles, neutralization of the complement factor $\mathrm{C} 3 \mathrm{~b}$ through factor $\mathrm{H}$ binding has been suggested (Hostetter, 1999; Ogunniyi et al., 2009), which implies that they would interfere with phagocytosis. This assumption is further sustained by the fact that the group B Streptococcus Pht homologue (named streptococcal histidine triad) seems also to bind factor H (Maruvada et al., 2009). However, other authors, through the use of Pht-deficient strains, concluded that these proteins do not bind factor $\mathrm{H}$ (Melin et al., 2010). In addition, a role in adherence is also suspected. Indeed, a genetic link between $p h t D$ and $l m b$, the latter encoding a putative laminin adhesion protein (Spellerberg et al., 1999), has been reported (Panina et al., 2003). Finally, due to the high number of histidine residues in the histidine triads, it has been suggested that the Pht proteins may be involved in DNA and/or metal binding (Adamou et al., 2001). More specifically, some studies highlighted a link between the Pht family and zinc. Indeed, AdcR-binding sites have been found in the upstream regions of the pht genes (Loisel et al., 2008), AdcR being described as a transcription factor that regulates zinc uptake (Panina et al., 2003). Furthermore, the crystal structure of a portion of PhtA revealed the presence of zinc ions bound to a histidine triad domain (RiboldiTunnicliffe et al., 2005). It is not clear, however, whether the function of those proteins is in zinc scavenging or transport, or whether zinc rather plays a conformational or functional role.

Important aspects of vaccine candidates that need to be addressed are their level of expression and associated regulation, their occurrence as well as their sequence variability. Therefore, we have addressed these different aspects with regard to the Pht proteins.

\section{METHODS}

Bacterial strains and culture conditions. S. pneumoniae strain TIGR4 (serotype 4) (Tettelin et al., 2001) was kindly provided by
Andrew Camilli (Tufts University School of Medicine, Boston, MA, USA). The WU2 strain (serotype 3) was kindly provided by David E. Briles (University of Alabama at Birmingham, Birmingham, AL, USA). The D39 strain (serotype 2) was kindly provided by J. C. Paton (University of Adelaide, Australia). The type 4 strain was obtained from the CDC (Centers for Disease Control \& Prevention, Atlanta, GA, USA).

Pneumococci were routinely grown in Todd-Hewitt broth (THB; Difco) with either $0.5 \%(\mathrm{w} / \mathrm{v})$ yeast extract or $17 \%$ fetal bovine serum (JRH Biosciences) at $37{ }^{\circ} \mathrm{C} / 5$ or $8 \% \mathrm{CO}_{2}$. When appropriate, erythromycin and/or spectinomycin (Sigma-Aldrich) were added at 0.2 and $1000 \mu \mathrm{g} \mathrm{ml}^{-1}$, respectively.

Escherichia coli DH5 $\alpha$ and JM109 strains (Gibco-BRL, Life Technology) were grown in Luria-Bertani (LB) broth (Difco) with or without $1.5 \%(\mathrm{w} / \mathrm{v})$ Bacto-agar (Difco) at $37{ }^{\circ} \mathrm{C}$ for $16 \mathrm{~h}$. When appropriate, erythromycin or spectinomycin was added to the growth medium at 500 and $100 \mu \mathrm{g} \mathrm{ml}^{-1}$, respectively.

To study Pht occurrence, in addition to 23 in-house and pneumococcal molecular epidemiology network (PMEN) strains, 34 isolates were provided by T. J. Mitchell (Scotland), six by R. E. Gertz (CDC, Atlanta, USA), two by A. B. Brueggemann (John Radcliffe Hospital, Oxford, UK) and nine by the American Type Culture Collection (ATCC). Among the isolates provided by T. J. Mitchell, four were used for immunoblotting experiments, namely 00-1621 (serotype 15B), 00-2292 (non-typed), FG404293 (serotype 9) and 002569 (non-typed).

DNA treatment and analysis. E. coli plasmid DNA was obtained by using a plasmid Midi or Mini purification kit (Qiagen). PCR products were purified with the QIAquick PCR purification kit, and DNA digests were purified on $1 \%(\mathrm{w} / \mathrm{v})$ agarose gel by using the QIAquick gel extraction kit (Qiagen). Restriction and ligation enzymes were obtained from New England BioLabs. The Expand high-fidelity system (Roche) was used for each PCR of these studies. All commercial products were used under conditions recommended by the suppliers.

DNA sequencing was carried out with the Big Dye terminator sequencing kit on an Applied Biosystems automated DNA sequencer (model 3100 or $3130 \mathrm{XL}$ ). Sequence analyses were performed with MacVector V6.5 software (Oxford Molecular), Vector NTI 7.1 software (Informax) or SeqMan software (Lasergene, DNASTAR), and sequences were compared with the available $S$. pneumoniae TIGR4 genome sequence (http://www.tigr.org) (Peterson et al., 2001).

S. pneumoniae genomic DNA extraction. Chromosomal DNA from each strain was obtained by harvesting confluent overnight growth from one or two heavily inoculated blood agar plates into $1 \mathrm{ml}$ TE $(10 \mathrm{mM}$ Tris/HCl, $5 \mathrm{mM}$ EDTA, $\mathrm{pH} 7.8)$. The bacterial suspension was centrifuged for $5 \mathrm{~min}$ at maximum speed in a microcentrifuge. The pellet was either treated with the QIAamp DNA mini kit protocol (Qiagen) or resuspended in $75 \mu \mathrm{l} \mathrm{TE}$, lysed by sequential addition of $20 \mu \mathrm{l}$ lysozyme $\left(100 \mathrm{mg} \mathrm{ml}^{-1}\right)$ and $20 \mu \mathrm{l}$ proteinase $\mathrm{K}\left(20 \mathrm{mg} \mathrm{ml}^{-1}\right)$ and incubated at $37{ }^{\circ} \mathrm{C}$ for $45 \mathrm{~min}$. Then, $500 \mu \mathrm{l}$ of lysis buffer $[10 \mathrm{mM}$ Tris/ $\mathrm{HCl}, \mathrm{pH} 8.0,0.14 \mathrm{M} \mathrm{NaCl}, 0.1 \mathrm{M}$ sodium citrate, $1 \mathrm{mM}$ EDTA, $\mathrm{pH} 8.0,0.1 \%(\mathrm{w} / \mathrm{v})$ sodium deoxycholate] was added and incubated for $10 \mathrm{~min}$ at room temperature. At the end of this incubation period, $250 \mu \mathrm{l}$ ammonium acetate (7.5 mM, pH 7.7) was added to the crude lysate and incubated for 10 min on ice. The viscous DNA was extracted twice with phenol/ chloroform/isoamyl $(25: 24: 1)$ and precipitated in isopropyl alcohol. The resulting DNA was washed with $70 \%(\mathrm{v} / \mathrm{v})$ ethanol and resuspended in $50 \mu \mathrm{l}$ TE containing $0.6 \mu \mathrm{l}$ RaseA $\left(10 \mathrm{mg} \mathrm{ml}^{-1}\right)$. DNA suspensions were stored at $4{ }^{\circ} \mathrm{C}$.

RNA isolation. Total RNA was isolated from pneumococci grown from an $\mathrm{OD}_{600}$ of 0.01 in $\mathrm{THB}$ to different $\mathrm{OD}_{600}$ values to evaluate 
gene expression at different growth phases (early exponential, $\mathrm{OD}_{600}$ 0.3 ; late exponential, $\mathrm{OD}_{600} 0.9$; stationary, $\mathrm{OD}_{600} 1.2$ ). Cells were centrifuged and resuspended in RNase-free Tris-EDTA containing $6 \mathrm{mg}$ lysozyme $\mathrm{ml}^{-1}$ and $1 \mathrm{mg}$ sodium deoxycholate $\mathrm{ml}^{-1}$, and incubated at room temperature for $10 \mathrm{~min}$. After incubation, RNA isolation was performed with the Qiagen RNeasy Mini kit following the manufacturer's instructions. Contaminating genomic DNA was eliminated by incubating RNA samples with 1 U DNase I ( $\mu$ g RNA) ${ }^{-1}$ for $1 \mathrm{~h}$ at $37^{\circ} \mathrm{C}$, followed by DNase inactivation with $2.5 \mathrm{mM}$ EDTA for $10 \mathrm{~min}$ at $65{ }^{\circ} \mathrm{C}$. Total RNA was quantified by using the Ribogreen RNA quantification kit (Molecular Probes) following the manufacturer's instructions.

5'-Rapid amplification of cDNA ends (RACE). The method used to identify transcription starts was adapted from that described by Ranasinghe \& Hobbs (1998). Briefly, a primer specific for the $3^{\prime}$ end of the phtE gene was used to synthesize the first-strand cDNA from total RNA with the Superscript II reverse transcriptase (Invitrogen), following the manufacturer's instructions. RNase A was then added for $1 \mathrm{~h}$ at room temperature to generate blunt $3^{\prime}$ ends on the cDNARNA hybrid. The hybrid was inserted into EcoRV-digested pKS plasmid (Stratagene) by using T4 DNA ligase (overnight incubation at $16{ }^{\circ} \mathrm{C}$ ). A PCR was set up to amplify the $5^{\prime}$ end by using another reverse $3^{\prime}$ end-specific phtE primer and $\mathrm{pKS}$-specific T7 promoter primer. Sequencing of the pKS-cDNA junction was performed to identify the +1 base.

Transcriptional terminator identification. Terminator identification was performed by using the Wisconsin Sequence Analysis Package version 10.1 (Genetics Computer Group) based on the method described by Brendel \& Trifonov (1984).

RT-PCR. RT-PCR studies were performed as follows. RNA $(2 \mu \mathrm{g})$ was first denatured for $5 \mathrm{~min}$ at $65{ }^{\circ} \mathrm{C}$ in a mixture containing $10 \mu \mathrm{M} \mathrm{3}$ end gene-specific reverse primer and $20 \mathrm{U}$ RNaseOut in a total volume of $10 \mu \mathrm{l}$. The reverse transcription reaction was then carried out by adding $5 \mathrm{mM}$ dithiothreitol, $1 \mathrm{mM}$ dNTP, $15 \mathrm{U}$ ThermoScript reverse transcriptase (Invitrogen), $1 \times$ cDNA synthesis buffer and RNase-free sterile water to a volume of $20 \mu \mathrm{l}$. The reverse transcription mixture was incubated at $56-58{ }^{\circ} \mathrm{C}$ for $1 \mathrm{~h}$, followed by reverse transcriptase denaturation for $5 \mathrm{~min}$ at $85^{\circ} \mathrm{C}$. The RNA strand on the RNA-cDNA hybrids was degraded by incubating the reverse transcription solution at $37{ }^{\circ} \mathrm{C}$ for 20 min with $1 \mathrm{U}$ RNase $\mathrm{H}$. PCR was carried with $2 \mu \mathrm{l}$ cDNA by using different $5^{\prime}$ gene-specific forward primers and the $3^{\prime}$ gene-specific reverse primers used for the reverse transcription reaction $(0.5 \mu \mathrm{M}$ final concentrations $), 0.2 \mathrm{mM}$ dNTP, Taq DNA polymerase reaction buffer, $2.5 \mathrm{U}$ Taq DNA polymerase (Amersham Biosciences) and sterile water to a volume of $50 \mu$ l. The PCR cycle consisted of initial denaturation at $94{ }^{\circ} \mathrm{C}$ for $5 \mathrm{~min}$, followed by $25-30$ cycles of denaturation at $94{ }^{\circ} \mathrm{C}$ for $15-30 \mathrm{~s}$, annealing at $55^{\circ} \mathrm{C}\left(p h t E\right.$, phtD) or $63{ }^{\circ} \mathrm{C}(p h t B$, phtD, phtA) for $15-$ $30 \mathrm{~s}$ and extension at $72{ }^{\circ} \mathrm{C}$ for $1 \mathrm{~min}$, and completed by a final extension step at $72{ }^{\circ} \mathrm{C}$ for 5-7 min. A negative control composed of RNA without the reverse transcription reaction was also conducted to exclude DNA contamination in the RNA preparation. PCR products were separated by $1 \%(\mathrm{w} / \mathrm{v})$ agarose gel electrophoresis and were visualized by ethidium bromide staining.

Preparation of Pht mutants. Cloning of mutator vectors was performed in E. coli DH5 $\alpha$ or JM109 plated on LB agar with the respective antibiotics. Transformation of E. coli with plasmid DNA was carried out by using standard methods with $\mathrm{CaCl}_{2}$-treated cells (Hanahan, 1985).

Mutator vectors were constructed from the pGEM-T vector (Promega) that replicates in E. coli but not in S. pneumoniae. They contain recombinant zones that correspond to the upstream and downstream regions of the pht genes to be deleted, amplified by PCR, surrounding an antibiotic-resistance gene. To prepare the quadruple Pht-deficient mutant, two different antibiotic-resistance genes had to be used to combine deletion in the two different loci (locus phtD/ $p h t E$, and locus $p h t A / p h t B)$. An erythromycin resistance gene (ermB), amplified from a derivative of the pJDC9 vector, was selected for the $p h t D / p h t E$ locus. For the $p h t A / p h t B$ locus, a spectinomycin-resistance gene [aad(9) gene], purified from the pR350 plasmid (kindly provided by J. Paton), was used.

Construction of the mutator vectors and the pneumococcal transformation protocol were carried out as fully described by Melin et al. (2010). All deletions were realized from start to stop codon, leaving the promoters and pre- and post-gene sequences untouched.

SDS-PAGE and Western blot analysis. Heat-killed bacterial suspensions were obtained by harvesting the confluent overnight growth from five heavily inoculated blood agar plates into $1 \mathrm{ml}$ sterile PBS (0.14 M NaCl, $2.7 \mathrm{mM} \mathrm{KCl}, 10 \mathrm{mM} \mathrm{Na} \mathrm{NPO}_{4}, 1.8 \mathrm{mM}$ $\mathrm{KH}_{2} \mathrm{PO}_{4}, \mathrm{pH} 7.2$ ), and incubating at $56{ }^{\circ} \mathrm{C}$ for $45 \mathrm{~min}$. For harmonization, all bacterial samples were resuspended at $0.02 \mathrm{OD}$ units $\mu \mathrm{l}^{-1}\left(\mathrm{OD}_{620}\right)$ and the same volume for each sample was loaded onto the gel. Sample buffer [60 mM Trizma base, $1 \%(\mathrm{w} / \mathrm{v})$ SDS, $10 \%(\mathrm{v} / \mathrm{v})$ glycerol, $0.01 \%(\mathrm{w} / \mathrm{v})$ Bromophenol blue, $2 \%(\mathrm{v} / \mathrm{v}) \beta$ mercaptoethanol] was added to the heat-killed suspensions. Preparations were boiled for $5 \mathrm{~min}$, centrifuged at maximum speed in a microcentrifuge for $2 \mathrm{~min}$ and separated by SDS-PAGE as described by Laemmli (1970). Proteins were electrophoretically transferred from acrylamide gels onto nitrocellulose membranes (Bio-Rad), according to Towbin et al. (1979). Membranes were probed with a mouse polyclonal antibody raised against $\mathrm{PhtD}$, followed by goat anti-mouse IgG conjugated to alkaline phosphatase (Promega). Enzyme-labelled bands were visualized with an NBT/ BCIP substrate system.

Culture growth in ion-deficient medium. The wild-type 4/CDC strain and corresponding Pht mutants were cultured under different conditions of ion depletion or supplementation in a chemically defined synthetic medium (MS) (Sicard, 1964). MS was supplemented with increasing concentrations of $\mathrm{Mn}^{2+}, \mathrm{Fe}^{2+}, \mathrm{Fe}^{3+}, \mathrm{Cu}^{2+}$ or $\mathrm{Zn}^{2+}$. $\mathrm{OD}_{620}$ was monitored during exponential phase and at stationary phase. Results were compared with those of the wild-type.

Wild-type WU2 strain was cultured with or without the $\mathrm{Zn}$-specific chelator $\quad N, N, N^{\prime}, N^{\prime}$,-tetrakis(2-pyridylmethyl) ethylenediamine (TPEN) to observe the effect of zinc depletion on Pht expression at the RNA (by RT-PCR) and protein (by flow cytometry) levels.

Flow cytometry. WU2 bacteria were grown in THB $+0.5 \%$ yeast extract at $37{ }^{\circ} \mathrm{C}, 8 \% \mathrm{CO}_{2}$, up to exponential phase. Alternatively, $30 \mu \mathrm{M}$ TPEN was added to the medium. After centrifugation, bacterial pellets were resuspended in a solution containing anti-PhtE, anti-PhtB/D, anti $\mathrm{PhtD} / \mathrm{E}$ or anti-type 3 polysaccharide monoclonal antibodies as control. After $2 \mathrm{~h}$ at $4{ }^{\circ} \mathrm{C}$, the solutions were centrifuged, the bacterial pellets were washed in $2 \%$ PBS-BSA and they were then incubated for $1 \mathrm{~h}$ at room temperature in AlexaFluorconjugated (Molecular Probes) goat anti-mouse secondary antibody in $2 \%$ PBS-BSA. After washing, cells were fixed in $0.25 \%$ PBSformaldehyde, and fluorescence-activated cell sorting analysis was performed. The median surface fluorescence was recorded.

Quantitative RT-PCR. Total RNA from strain D39 grown to an $\mathrm{OD}_{600} \sim 0.5$ (mid exponential) was purified by using the RNeasy Midi kit (Qiagen) and quantified with the Quant-iT RiboGreen RNA assay kit (Invitrogen). Samples $(1 \mu \mathrm{g})$ were processed twice with $1.5 \mu \mathrm{RQ} 1$ RNase-free DNase (Promega) for $30 \mathrm{~min}$ at $37^{\circ} \mathrm{C}$. The reaction was stopped by the addition of $1 \mu \mathrm{l}$ DNase STOP followed by incubation 
for $10 \mathrm{~min}$ at $65^{\circ} \mathrm{C}$. First-strand cDNA was generated using SuperScript II Reverse Transcriptase (Invitrogen), random primers (Invitrogen) and recombinant RNasin RNase inhibitor (Promega). Real-time PCR was carried out in a $50 \mu \mathrm{l}$ reaction volume by using the TaqMan PCR core reagents kit (Applied Biosystems), as described by the manufacturer. The following primers and probes were used: gyrB, GGGAAATAGCGAAGTGGTCAAG (forward), GGAATCGGAGAAGGCTTCAC (reverse) and TTACCAATCGCCTCTTC (probe); $p h t D$, CCCATGCGGACAATATTCG (forward), TGACTGCGTTCCTGCTTCTG (reverse) and CGTTTAATCTCTTCTTTTGT (probe).

All assays were performed in duplicate (from culture to quantitative PCR) and the relative gene transcription was analysed by the $2^{-\Delta \Delta \mathrm{C}_{\mathrm{T}}}$ method (Livak \& Schmittgen, 2001) by using gyrB as internal control and growth in THB alone as calibrator.

Determination of Pht occurrence. To select representative strains of $S$. pneumoniae, the population structure was analysed according to the strain genotype as determined by MLST (multi-locus sequence type; http://www.mlst.net). Based on MLST isolate sequence type (ST), major clonal lineages were determined. For each group, representative strains were selected for occurrence analysis, which was carried out by Western blotting on whole bacterial extracts with anti-PhtD polyclonal antibodies (cross-reactive with PhtA, PhtB and $\mathrm{PhtD}$ ) or anti-PhtE, and by PCR on pneumococcal genomic DNA with primers specific for PhtA, PhtB, PhtD or PhtE.

DNA sequencing for PhtD conservation analysis. DNA of 107 MLST-selected strains was amplified by PCR by using PhtD-specific oligonucleotide primers. The 107 sequences were aligned via the CLUSTAL_X program and the percentage identity between the sequences was computed by using a program written by the authors. Percentage identity was defined as (number of identities/length of shortest sequence) $\times 100$.

\section{RESULTS}

\section{Characterization of the pht genes}

Genomic organization of the pht genes. In a previous study, DNA sequencing of overlapping clones from an $S$. pneumoniae strain SP64 genomic library (Hamel et al., 2004) and PCR analyses allowed deduction of the genomic organization of the pht genes and their neighbouring genes in this type 6B strain. The phtA and $p h t B$ genes, as well as the $p h t D$ and $p h t E$ genes, were organized as a pair. BLAST analyses (http://www.tigr.org) (Peterson et al., 2001) indicated that the two gene tandems were located about $161 \mathrm{kbp}$ apart in the S. pneumoniae TIGR4 genome and that the genomic organization was identical to that observed in the SP64 strain (Fig. 1). The same pht gene organization was also found in the 4/CDC strain and in the WU2 strain, with the exception that phtA is missing in the latter (data not shown). Sequencing of the regions surrounding the pht genes on the TIGR4 strain DNA confirmed the latter observation (data not shown). Additional analysis demonstrated that $p h t A$ and $p h t B$ were separated by $157 \mathrm{bp}$, whereas phtD and phtE were separated by $209 \mathrm{bp}$ in the TIGR4 strain, which was chosen for further study.

On the phtD-phtE tandem side, a gene showing $72 \%$ sequence similarity to the group A and B streptococci $\operatorname{lmb}$ genes, coding for laminin-binding proteins [GenBank accession nos. AAK34689 (Ferretti et al., 2001) and AAD13796 (Spellerberg et al., 1999), respectively], was located 7 bp upstream of the phtD gene (Fig. 1). This gene product was also recently denoted as AdcAII, and described as an $\mathrm{ABC}$ transporter-like zinc-binding protein (Loisel et al., 2008). A 1392 bp ORF, located $142 \mathrm{bp}$ upstream of the $\operatorname{lmb}$ gene homologue, codes for a protein showing $64 \%$ sequence similarity to the Bacillus subtilis metabolite transporter YfnA protein (accession no. D69814) and $81 \%$ similarity to a putative amino acid permease of Streptococcus pyogenes (accession no. AAK33157) (Ferretti et al., 2001; Kunst et al., 1997). A sequence showing $79 \%$ identity to the first $481 \mathrm{bp}$ of $p h t E$ (proposed $p h t F$ ) was found $226 \mathrm{bp}$ after the $p h t E$ stop codon (Fig. 1). This sequence also showed $72 \%$ identity to the $p h t A, p h t B$ and $p h t D$ genes.

On the phtA-phtB tandem side, a 1332 bp ORF, showing $73 \%$ sequence similarity to the Streptococcus salivarius ptsI gene (accession no. P30299) (Gagnon et al., 1992), was located $253 \mathrm{bp}$ upstream of the phtA gene (Fig. 1). No functional ORF was located immediately downstream of the two gene pairs.

Transcriptional organization of pht genes. The genomic organization of pht genes suggested that the tandem genes might be coordinately transcribed. Further studies were thus performed to examine this hypothesis. First, putative promoters and ribosome-binding sites of pht genes were identified. 5'-RACE on the phtE gene allowed the identification of its transcription start, from which the promoter region was deduced. The transcription start site $(+1)$ was found to be located 96 bases upstream of the PhtE translation start site, downstream of typical $S$. pneumoniae -10 and -35 RNA polymerase binding sites (Morrison \& Jaurin, 1990) and upstream of a ribosomebinding site (Fig. 2a). Similar sequence organization was found upstream of the phtA, phtB and $y f n A$ genes, indicating the presence of putative promoters (Fig. $2 b, c$, e). However, due to the close proximity of the lmb gene

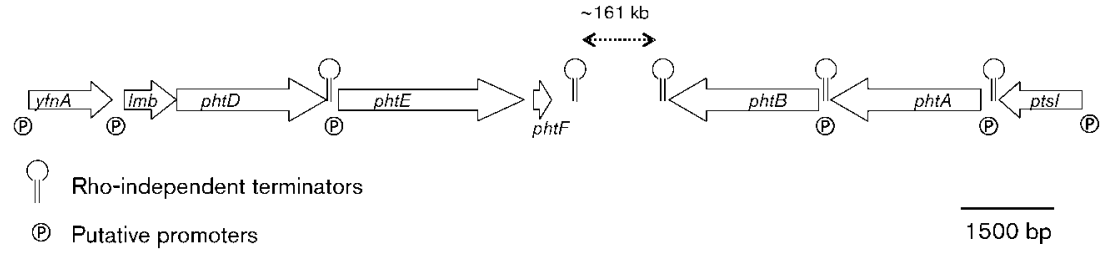

Fig. 1. Organization of the pht genes in $S$. pneumoniae serotype 4 strain TIGR4. 
(a)

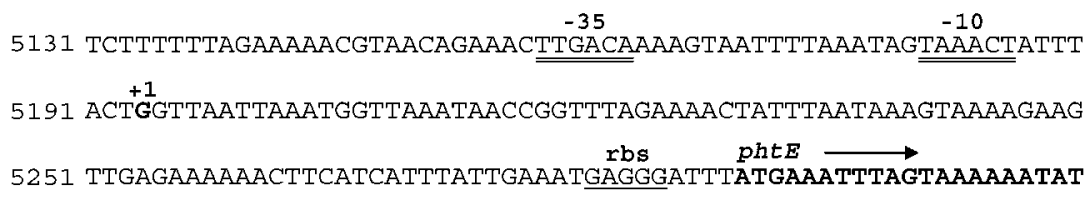

(b) $\begin{array}{ccc}-35 & -10 & +1 \\ 2341 \text { AAAATTCTTGACAAGTTGATATTTAGGAGTAAACTATTAACCAGTTAATAATAGAGAG } & \end{array}$ rbs 2401 GAGTTTCTGCAATTTAGAAATGAATTGCAACTAGAAATATCAAATAGAAAGAGAGTTTCG phtA

2461 ATGAAAATTAATAAGAAATACCTTGTTGGTTCTGCGGCAGCTTTGATTTT

(c) 4969 TTCTTGACAAGCAATATTAAAAAGAGTAAACTATTAACTAGTTAATTAACCGGTTTATTA

(d)

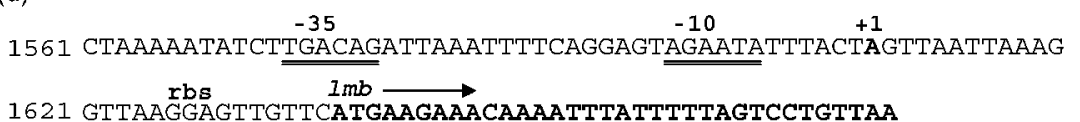

(e) 1 GTTACGGTAGTCAGATTTTTTTAGAAAAACATTTTATAAATATTCACATATCTCCTATAT 61 TTATGGTAAAATAGAATTATCAGTTTATTTTGGAGTCAAAGATGATATATTTAGAACAA
Fig. 2. Promoter-containing upstream regions of the pht genes in the TIGR4 strain. The upstream regions of the phtE gene (a), phtA gene (b), phtB gene (c), Imb gene (d) and $y f n A$ gene (e) are shown. The -35 and -10 regions are double-underlined, transcription start sites are indicated by bold type and " +1 ", putative ribosome-binding sites (rbs) are underlined and ORFs are represented by arrows indicating the direction of transcription over letters in bold type. The numbers on the left correspond to sequence positions in sequences with GenBank accession nos AY569979 (a, d, e) and AY569980 (b, c).
(7 bp), no promoter sequence was identified for the phtD gene. On the other hand, a sequence identical to the -35 sequences of the other pht genes was located upstream of the $\operatorname{lmb}$ gene (Fig. 2d). Ribosome-binding sites were observed 5-7 bp upstream of all start codons.

Transcription termination sites of pht and adjacent genes were also identified. Computer analysis of predicted mRNA secondary structures suggested the presence of stem-loop terminator-like structures at the $3^{\prime}$ ends of genes. Hairpin structures could form with calculated free energies of dissociation $(\Delta G)$ of $-9.4,-27.0,-16.8$ and $-21.6 \mathrm{kcal} \mathrm{mol}^{-1}$ for $p h t B$, phtD, phtA and ptsI, respectively, as determined by the method described by Turner et al. (1988) (Fig. 3). In fact, the terminator identified for the phtD gene was identical to that reported by the TIGR website for ORF SP1003, which corresponds to the phtD gene homologue (http://www.tigr.org). No transcription terminators were identified by the TIGR group for the other pht or surrounding genes, probably reflecting differences in the algorithms used by the two studies. Most hairpins ended with a stretch of $\mathrm{T}$ residues as typically found in prokaryotic transcription terminators (Rosenberg \& Court, 1979) and were located within $70 \mathrm{bp}$ downstream of stop codons (Fig. 3). Interestingly, the phtE terminator sequence $\left(\Delta G=-4.7 \mathrm{kcal} \mathrm{mol}^{-1}\right)$ was located $1867 \mathrm{bp}$ downstream of its stop codon and of the $p h t F$ gene, the latter ORF containing in-frame stop codons preventing its translation (Fig. 3a). No terminator sequences were identified downstream of $y f n A$ and $\operatorname{lmb}$ genes.

The genomic organization suggested that $p h t E$ could be part of an operon composed of the $y f n A, \operatorname{lm} b$, phtD, phtE and phtF genes. Nevertheless, the 5'-RACE (Fig. 2a) and terminator identification (Fig. 3a) indicated that $p h t E$ was the first gene transcribed on a bicistronic message, composed of $p h t E$ and $p h t F$ genes, which was confirmed by RT-PCR. The regions $p h t E$ to $p h t F$ were amplified by RT-PCR (Fig. 4a, lanes 4 and 6), whereas no amplification product was obtained with the primer pair specific to the region between genes $p h t D$ and phtE (Fig. 4a, lane 5), indicating transcriptional termination downstream of $p h t D$ (Fig. 3c).

As shown in Fig. 4(a) (lanes 1-3), the regions $y f n A$ to $p h t D$ were amplified by RT-PCR. Moreover, Loisel et al. (2008) have demonstrated that this phtD transcript also encodes, in addition to $y f n A, \operatorname{lm} b$ and $p h t D$, the two genes upstream of $y f n A(c c d A$, which is involved in the biogenesis of cytochrome $c$, and spr0904, which shows similarity to 


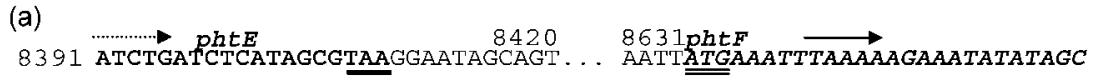

8661 AGCTGGATCTGTTGTTATCCTTTCCTTAAGTCTGTGTGTTTATGCTCTGAACCAACATAG

8721 CTAACAGGCCAATACAGATAAAAATCGTGTTTCATATGTAAACAGTAATAAAGACACTAA

8781 GAAGACTGAAAATTTGACTCCAGACTAGGT ...TCAGTTAGGTTAAGGGAGGATATATTATTAA

9021 GGTAGATGGAAAGTATTATGTTTACCTTAAAGATCAAGCTCATGCAGAAAATGTACGAAC

9081 AAAAGATGAAATCAATCGCCAAAAACAAGAACATGGTAAA. . TAGCGCCCTTCAACAAGAAA

10281 AGGAAAATGCTGAGCAAGATCCTCAGACACTTGTACTCTATCAAAAACTC

(b) 7511 AAACTATTGGCTTTATTAAAGGAGAGTAAGTAAAGGTAGCAGCATTTTCTAACTCCTAA
7571 AACAGGATAGGAGAACGGGAAAACGAAAAATGAGAGCAGAATGTGAGTTCTAGTTCTCA
7631 TTTTTTTCATGAAAT

(c) 5051 AAAGAAAGTCAACCGGCTCCTATACAGTAGTAAAATGAATGGAGCATATTTTATGGAGAA 5111 GTAACCTTTCGTGTTACTTCTCITTTTTAGAAAAACGTAACAGAAACTTGACA

(d)

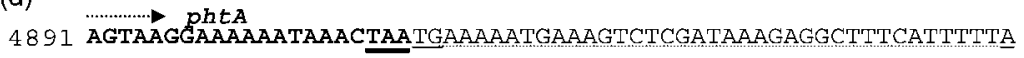
4951 TTATGTATATATGTAAAATTCTTGACAAGCAATATTAAAAAGAG

(e) 2191 ACGTTA 2251 TTTAAA
Fig. 3. Rho-independent transcription terminator sequences of the pht and pts/ genes in the TIGR4 strain. The terminator regions of phtE (a), phtB (b), phtD (c), phtA (d) and pstl (e) genes are shown. Stop codons are underlined and in bold type, terminator regions are underlined, and sequences underlined with a dotted line indicate the hairpin region of the terminators. ORFs are represented by arrows indicating the direction of transcription over letters in bold type. In (a), the region in italics (phtF gene; putative start codon doubly underlined) shows $78 \%$ identity with the first $481 \mathrm{bp}$ of the phtE gene. However, underlined stop codons prevent significant gene translation. Numbers correspond to sequence positions in the sequences with GenBank accession nos AY569979 (a, c) and AY569980 (b, d, e). thioredoxine). Interestingly, the identification of a putative promoter upstream of the $\operatorname{lmb}$ gene (Fig. 2d) suggested transcriptional coupling of the $p h t D$ and $\operatorname{lm} b$ genes.
Results obtained for the $p h t B$ and $p h t A$ genes showed that they were transcribed as monocistronic mRNAs, as was suggested by identification of promoter (Fig. 2b, c) and

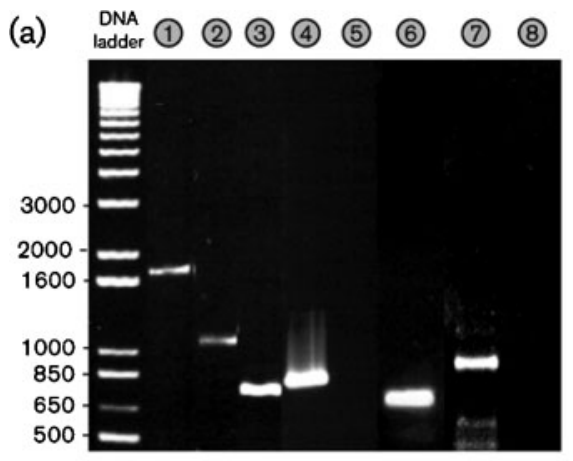

(b)

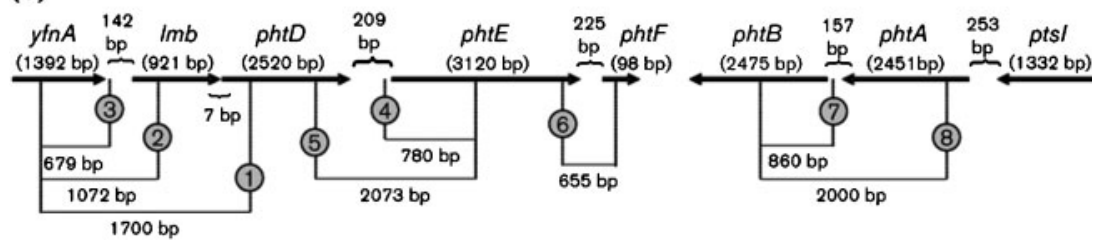

Fig. 4. RT-PCR analyses of the pht transcripts in TIGR4. (a) The RT-PCR products with template RNA from cells grown to midexponential growth phase were separated in a $1 \%$ agarose gel. Lanes $1-8$ correspond to regions $1-8$ in the schematic representation (b). The RT-PCR products shown in lanes 1-8 were generated by using primer pairs that flanked the corresponding regions depicted in the scheme. The length of each predicted RTPCR product is indicated under the corresponding interval. The length of each gene is indicated in parentheses. 
terminator (Fig. 3b, d) sites. Analysis of the transcriptional organization of $p h t A$ and $p h t B$ by RT-PCR revealed a $p h t B-$ specific amplicon with $p h t B$-specific primers (Fig. $4 \mathrm{a}$, lane 7). No amplification product was obtained by RT-PCR with primers amplifying the region between $p h t A$ and $p h t B$ (Fig. 4a, lane 8), indicating a monocistronic organization of the $p h t A$ and $p h t B$ genes. Terminator site identification (Fig. 3e) indicated that ptsI is transcribed as a monocistronic message, which also confirmed that phtA is not part of a polycistronic transcript.

\section{Construction and use of Pht mutants}

Characterization of the mutants. Pht $\mathrm{A}, \mathrm{PhtB}, \mathrm{PhtD}$ and PhtE mutants and quadruple PhtABDE mutant were constructed. To assess the accuracy of the recombination, the genomic DNA of the mutant strains was purified and the recombinant regions were sequenced (data not shown). Furthermore, the mutants were characterized phenotypically by immunoblotting, by using a mouse polyclonal anti-PhtD antibody (Fig. 5). All four Pht isotypes were recognized by this antibody. However, PhtE bands were fainter, confirming the greatest divergence of this Pht from the three other isotypes.

Influence of various ions on bacterial growth. Growth of the Pht quadruple mutant was dramatically decreased in MS, compared with that of the wild-type strain and of the different Pht mutants (Fig. 6a). The PhtA, PhtB and PhtE single mutants behaved the same way as the wild-type and the PhtD single mutant (data not shown). When the medium was supplemented with up to $200 \mu \mathrm{M} \mathrm{Fe}^{2+}, \mathrm{Zn}^{2+}$ or $\mathrm{Mn}^{2+}$, growth of the wild-type and of the $\mathrm{PhtD}$-deficient mutant was slightly ameliorated (growth rate versus MS alone: $96-130 \%)$. In contrast, the behaviour of the quadruple mutant was striking. Whereas the addition of

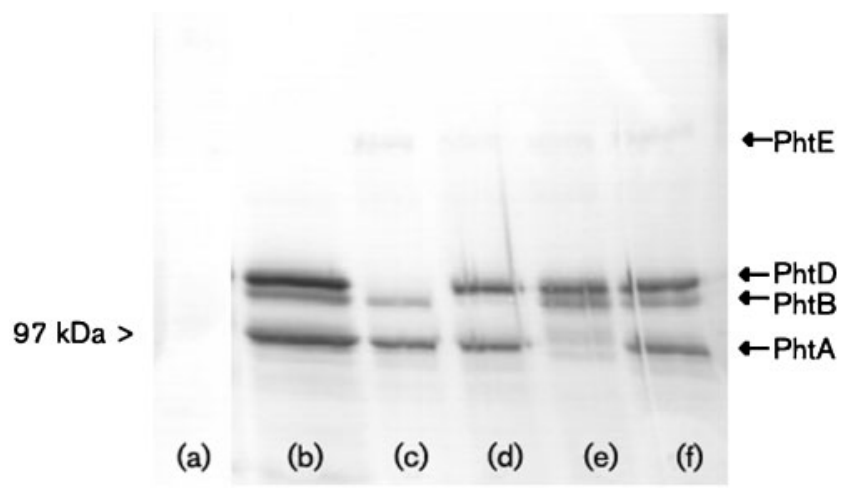

Fig. 5. SDS-PAGE immunoblotting of bacterial extracts. Anti-PhtD antibody was used to probe extracts from the PhtABDE quadruple mutant (a), the PhtE mutant (b), PhtD mutant (c), PhtB mutant (d), PhtA mutant (e) and the wild-type 4/CDC (f) strains. The position of the different Pht bands is indicated on the right, and a molecular mass marker on the left.
$200 \mu \mathrm{M} \mathrm{Fe}{ }^{2+}$ to $\mathrm{MS}$ induced only a $25.3 \%$ increase of growth (Fig. 6d), the same concentration of $\mathrm{Zn}^{2+}$ or $\mathrm{Mn}^{2+}$ restored the growth capacity of the quadruple mutant (Fig. $6 \mathrm{~b}, \mathrm{c})$. This represents an up to $92.3 \%$ increase in growth rate compared with that obtained in MS alone. However, this recovery of growth rate was delayed, visible only after overnight incubation, as no improvement was visible within the first few hours of culture. The addition of $\mathrm{Mg}^{2+}$ at $200 \mu \mathrm{M}$ did not restore growth completely, as did $\mathrm{Zn}^{2+}$ or $\mathrm{Mn}^{2+}$, but similar increases in growth rates were obtained when $\mathrm{Mg}^{2+}$ was added at $1 \mathrm{mg} \mathrm{ml}^{-1}$ to MS (data not shown). The addition of high concentrations of $\mathrm{Cu}^{2+}$ $(200 \mu \mathrm{M})$ or $\mathrm{Zn}^{2+}(1 \mathrm{mM})$ was toxic for wild-type and mutant strains (data not shown).

Effect of zinc depletion on pht expression. When the zinc chelator TPEN was added to the culture medium, the expression level of the Pht proteins in the WU2 genetic background was increased, as determined by flow cytometry experiments (Fig. 7a, b, c). As a control, no shift in mean fluorescence was observed with anti-type 3 polysaccharide antibody under the same conditions of zinc depletion (Fig. 7d). At the RNA level, we measured (RTPCR) an up to 25-fold increase in the phtE transcription level under conditions of zinc depletion (data not shown).

In addition, quantitative RT-PCR experiments were performed with mRNA purified from a pneumococcal isolate (D39 strain) grown in either THB or THB $+25 \mu \mathrm{M}$ TPEN. The concentration of chelator added to the media was suboptimal, as determined with preliminary experiments, meaning that TPEN did not prevent growth (as observed when TPEN concentration was sufficient to chelate all ions in the media) but delayed it (data not shown). The addition of TPEN to the medium resulted in a 4.84-fold increase in phtD mRNA expression level. Complementation of THB + TPEN with $25 \mu \mathrm{M} \quad \mathrm{ZnSO}_{4}$ restored the phtD mRNA expression to a level similar to that observed in medium alone, suggesting that among all ions that can be chelated by TPEN ( $\mathrm{Zn}, \mathrm{Mn}, \mathrm{Cd}, \mathrm{Co}, \mathrm{Ni}, \mathrm{Cu}, \mathrm{Mg}, \mathrm{Ca}$ ) $\mathrm{Zn}$ has the major impact on phtD expression level.

\section{Occurrence of Pht in pneumococci}

In total, 74 strains (including 23 PMEN and in-house strains) were investigated. In this set of representative strains, 18 clonal lineages were characterized by 56 different STs, among which the more represented were $81,90,124$, 156, 162 and 199 (22 strains), and 27 different serotypes, among which the more represented were $19 \mathrm{~F}, 6 \mathrm{~B}, 3$ and $23 \mathrm{~F}$ ( $47 \%$ of all strains). Forty-six strains $(61 \%)$ with 27 different STs belonged to three major clonal groups (founder sequence: ST156, ST81 and ST199).

By PCR on genomic DNA, we found the genes for PhtD, PhtE, PhtB and PhtA in 100, 97, 81 and $62 \%$ of the strains, respectively. Fifty-four per cent of the strains were found to carry the four pht genes in their genome. On immunoblots with polyclonal antibodies raised against $\mathrm{PhtD}$, we detected 

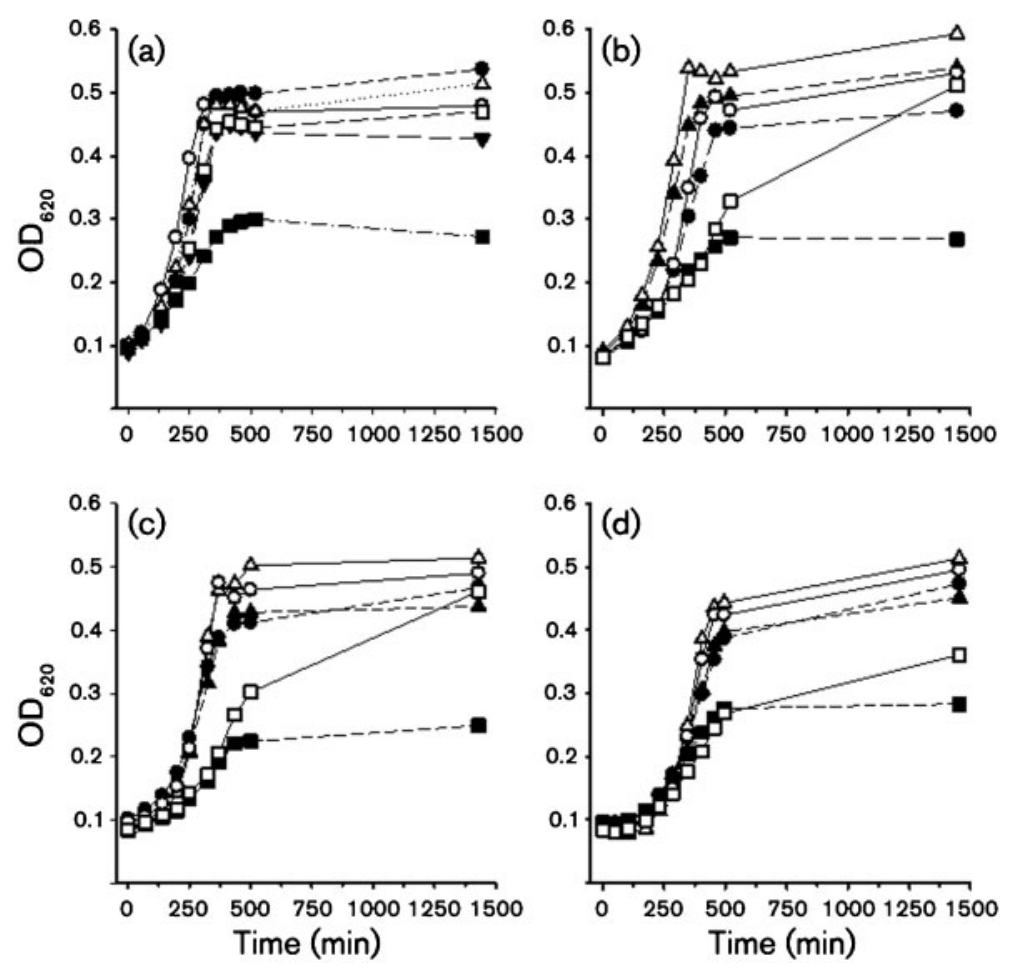

Fig. 6. S. pneumoniae requires $\mathrm{Pht}$ proteins to grow in a poor medium. (a) Growth curves of 4/CDC wild-type strain and different Phtdeficient mutants in MS. $\bigcirc$, Wild-type; $\nabla$, PhtD mutant; $\square$, PhtBD mutant; $\bigcirc$, PhtDE mutant; $\triangle$, PhtBDE mutant; $\mathbf{\square}$, PhtABDE. (b-d) Growth curves of the wild-type (triangles), PhtD-deficient (circles) and Pht quadruple mutant (squares) were also determined in MS with (open symbols) or without (filled symbols) $200 \mu \mathrm{M} \mathrm{Zn}{ }^{2+}$ (b), $200 \mu \mathrm{M} \mathrm{Mn}{ }^{2+}$ (c) or $200 \mu \mathrm{M} \mathrm{Fe}{ }^{2+}$ (d). Each figure depicts the results of one representative experiment of three.

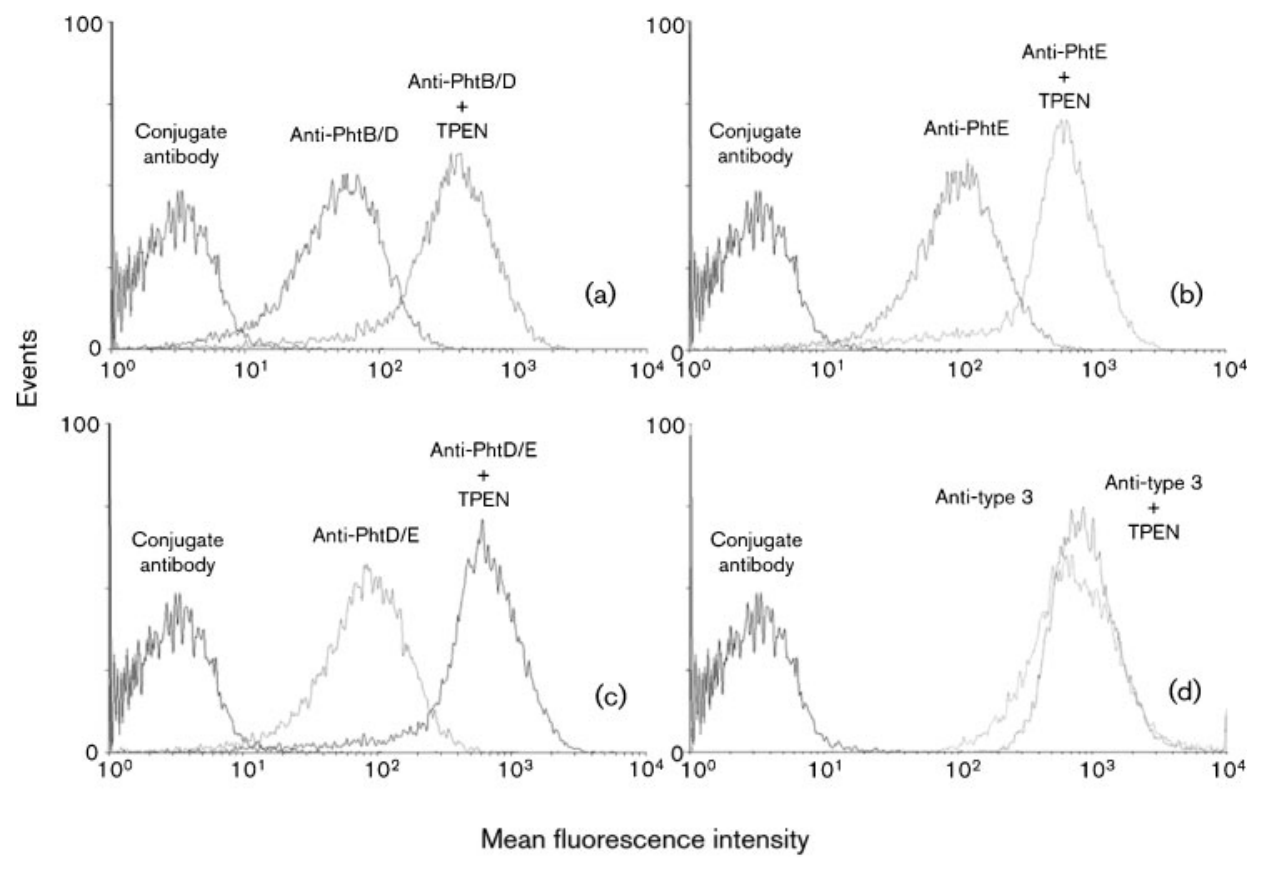

Fig. 7. Expression of the Pht proteins is regulated by zinc. WU2 bacterial cells were cultured with or without TPEN $30 \mu \mathrm{M}$, a zinc chelator. Next, cells were probed with anti-PhtB/D (a), anti-PhtE (b), anti-PhtD/E (c) or anti-type 3 polysaccharide (d) antibodies followed by AlexaFluor-conjugated goat anti-mouse secondary antibody before they were analysed by flow cytometry. As controls, cells were incubated with the secondary conjugate antibody. Representative FACS plots of the different conditions are shown. 
PhtD in all strains. Likewise, the other Pht isotypes were found by immunoblotting in all strains that carry their respective genes. Notably, due to the highest genetic divergence, PhtE was better detected with a polyclonal antibody specifically raised against it (Fig. 8). Some peculiar Pht isotypes were found, such as a PhtE of a lower size (10 kDa smaller) in six isolates, and of an even smaller size (20 kDa smaller) in eight strains. Likewise, four strains were found to produce a truncated PhtA (Fig. 8 ), the gene of which was not detected by PCR. Interestingly, these four strains also expressed the 20$\mathrm{kDa}$-truncated PhtE. Sequencing of the $p h t A / B$ locus of pht $B$-negative strains revealed that the only gene present in this locus was a hybrid between either $p h t A$ and $p h t B$ or phtA and phtD genes.

Interestingly, sequence analysis demonstrated that the signal sequence encoded by pht genes was specific for each Pht family member. Indeed, the specific signal sequence of a Pht family member differs at least in one position from the signal sequence of another Pht family member (Table 1).

Next, we attempted to determine whether links can be made between the Pht expression profile and the isolate genotype/serotype. In the strains analysed, all serotype 2, 4, $14,6 \mathrm{~B}$ and $7 \mathrm{~F}$ isolates possessed the four Pht isotypes, and all serotype 3, 9, $19 \mathrm{~F}$ and $22 \mathrm{~F}$ isolates lacked PhtA or carried a smaller PhtA.

Regarding a potential link between MLST genotype and Pht expression profile, the following features were noted: the $10-\mathrm{kDa}$-truncated $\mathrm{PhtE}$ was found mainly in the genotype ST199 group. The serotypes of these strains are 19F, 19A, 15A, 1 and 6A. The 20-kDa-truncated PhtE was observed in eight isolates that all belonged to the same clonal lineage (founder sequence ST156), but carrying different serotypes (9, 19A, 19F and 14). Finally, strains lacking PhtA were observed in different clonal lineages. Therefore, no major link between lack of PhtA and genotype was identified.

\section{PhtD conservation}

In our study of Pht occurrence, PhtD was found to be present among all pneumococcal strains tested, making it the best vaccine candidate among the Pht family. In this respect, it was essential to determine the level of sequence conservation among pneumococcal strains; therefore, DNA sequencing was carried out.

From the analysis of 107 strains (based on MLST classification), it was determined that $\mathrm{PhtD}$ varies in length between 831 and 853 amino acids and has a molecular mass of around $100 \mathrm{kDa}$. PhtD was found to be highly conserved among the 107 strains tested and only one sequence displayed a stop for a truncated protein (strain 4/ 75 , serotype 4 ). The proline-rich region contained 13-15 prolines for all strains (in seven strains, only 11-13 prolines). Limited stretches of variability of $<4$ amino acids were found in the sequence of PhtD.

\section{DISCUSSION}

The Pht proteins are promising candidates to be incorporated in a vaccine against pneumococcal infectious diseases. In that respect, it appeared crucial to investigate how the expression of these proteins is regulated and to better define their role in pneumococcal pathogenesis.

Genome analysis, combining the results obtained in the 4/ CDC, TIGR4 and WU2 strains, showed that the four gene homologues are arranged in double tandem. The presence of a fifth, although truncated, member of the pht gene family downstream of the phtE gene was also shown, confirming the finding in a previous study (Adamou et al., 2001). It seems that this truncation is conserved as the same organization was found in the S. pneumoniae strain R6 genome (accession no. AAK99714) (Hoskins et al., 2001).

Our study showed that the tandem organization of the pht genes does not correlate with a pht bicistronic transcription. None of these genes was co-transcribed with its

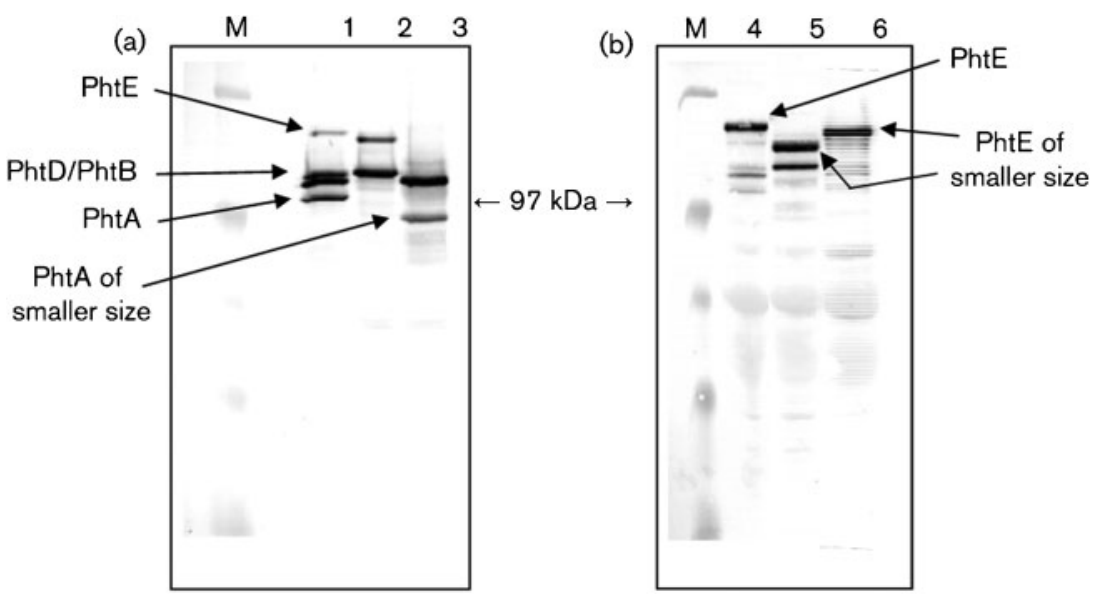

Fig. 8. Western blot analysis illustrating the different SDS-PAGE migration patterns of the Pht protein family. Whole-cell extracts were separated by using SDS-PAGE and immunoblotted. Strains D39 (serotype 2, ST595), 001621 and 00-2292 (lanes 1, 2 and 3, respectively) were probed with a polyclonal anti-PhtD (a), and strains D39, FG404293 and 00-2569 (lanes 4, 5 and 6, respectively) with a polyclonal anti-PhtE (b). Molecular mass markers are shown in lane $\mathrm{M}$. 
Table 1. Signal sequence comparison of each Pht family member

Amino acids conserved in at least three Pht family members are shown in bold.

\begin{tabular}{|lcc|}
\hline Signal sequence of: & No. of sequences analysed & Signal sequence \\
\hline PhtA & 7 & MKINKKYLVG-SAAALILSV \\
PhtB & 8 & MKINKKYLAG-SVATLVLSV \\
& 72 & /V \\
PhtD & 8 & MKINKKYLAG-SVAVLALSV \\
& & /V \\
PhtE & 8 & MKFSKKYIAAGSAVIVSLSL \\
\hline
\end{tabular}

related pht neighbour under the conditions tested. Promoter and terminator analyses correlated well with traditional RT-PCR studies. We found evidence that the $p h t B, p h t A$ and $p h t E$ genes possess individual putative promoters and that mRNA transcription probably ends soon after the corresponding stop codons. On the other hand, the phtD gene was different in that no promoter was identified in silico for this gene. Instead, promoters, but no transcription terminators, were identified for $\operatorname{lm} b$ and $y f n A$, two genes located upstream of phtD, which tended to indicate that those genes are organized in an operon system. This corroborates the recent finding that phtD may be expressed in a large operon system together with the four genes upstream (Loisel et al., 2008). Nevertheless, the fact that a promoter was identified for $y f n A$ and for $\operatorname{lm} b$ indicates that transcription may start at these locations, meaning that phtD-containing transcripts of different length may be produced. In addition, an adcR binding site was identified upstream of the $\operatorname{lmb}$ gene (Loisel et al., 2008; Panina et al., 2003), suggesting that a zinc-regulated bicistronic transcript with $\operatorname{lm} b$ and phtD may also exist. In line with this, Spellerberg et al. (1999) showed that the group B streptococcal $\operatorname{lmb}$ gene is co-transcribed with a gene whose product shows $67 \%$ sequence similarity to the first 225 (phtE) and first 228 (phtA, phtD and phtB) amino acids of pht gene products (accession no. AF062533). A comparable genomic arrangement was also observed in the group A streptococcal genome (Ferretti et al., 2001). Furthermore, it was proposed that co-transcription of $\operatorname{lmb}$ and $p h t D$ indicates a functional link, with the former gene product being involved in pneumococcal adhesion and invasion (Panina et al., 2003).

It is interesting to note that the phtD gene can be transcribed as a polycistronic message with the two other genes, namely $y f n A$ and $\operatorname{lm} b$, which may be involved in transport and specific binding activities, respectively. Indeed, YfnA in S. pneumoniae (Hoskins et al., 2001) and the homologous proteins in Bacillus subtilis (Yamamoto et al., 1997), S. pyogenes (Ferretti et al., 2001) and Streptococcus mutans (Ajdić et al., 2002) are thought to be amino acid transporters, members of the superfamily of permeases. The Lmb protein has been described as an ABC transporter-like zinc-binding protein (Loisel et al., 2008) and a putative laminin-binding protein (Spellerberg et al., 1999). Indeed, this protein shows similarities to an adhesin family known as LraI found initially in oral streptococci (Jenkinson, 1994) and since then discovered in other streptococci and other genera (Cockayne et al., 1998). It was suggested that LraI-like proteins are involved in the colonization of human epithelium by streptococci and their subsequent invasion into the bloodstream (Elsner et al., 2002). It is not clear why $y f n A, \operatorname{lmb}$ and $p h t D$ are associated in an operon system. One plausible hypothesis is that those three proteins are required at the same moment of the bacterial cyclus, for invasion or growth, for instance, without necessarily being associated in their functions. Determination of the role of the Pht proteins might give some clue to this genomic association. Regarding their role, we can first speculate that similarities between intra-species Pht proteins are indicative of interchangeability. These proteins might also share similar functions through their homologous regions and, at the same time, exert distinct activities, even at different development phases of the bacterium, through their variable regions. The results we have obtained from immunoblotting with protein extracts from the various Pht-deficient mutants tend to show that there is no compensation for gene loss by increasing the level of expression of the remaining pht gene products. This feature was also described recently at the RNA level by using RT-PCR (Ogunniyi et al., 2009).

As already mentioned, all Pht proteins share histidine triad motifs (Adamou et al., 2001; Hamel et al., 2004; Zhang et al., 2001), thought to be involved in metal binding. Interestingly, it has been speculated that these motifs might be more involved in zinc binding, especially to generate conformationally functional Pht proteins (Panina et al., 2003). The same authors also hypothesized that a zincrestricted environment induces the expression of the Pht proteins and favours Streptococcus colonization and invasion. In this context, we carried out experiments in which wild-type and Pht-deficient strains were cultured under different conditions of ion depletion and supplementation. In MS, wild-type and PhtD-deficient strains grew more slowly than in rich LB medium, but almost no growth of the quadruple Pht-deficient mutant was observed in the minimal medium. Strikingly, when $\mathrm{Zn}^{2+}$ or $\mathrm{Mn}^{2+}$ was added, growth of the quadruple mutant was restored up to that of the wild-type, and this was particularly visible at concentrations between 20 and $200 \mu \mathrm{M}$. However, our results show that growth of the quadruple mutant was 
delayed compared with the wild-type. Triple and double mutants, expressing only one of the four Pht proteins, were also constructed and used in this type of experiment. From these investigations it appeared that strains with only one Pht type behave as wild-type strains, suggesting redundancy inside the Pht protein family.

These observations, besides confirming the requirement of $\mathrm{Zn}^{2+}$ and $\mathrm{Mn}^{2+}$ for bacterial growth, argue for a critical role of the Pht family in $\mathrm{Zn}^{2+}$ and $\mathrm{Mn}^{2+}$ uptake. The fact that $\mathrm{Zn}^{2+}$ deprivation induces de novo synthesis of proteins of the Pht family and that $\mathrm{Zn}^{2+}$ addition represses it is a further argument to support a close relationship between $\mathrm{Pht}$ and $\mathrm{Zn}^{2+}$. This regulation is likely to occur through AdcR protein regulating zinc uptake in $S$. pneumoniae. Indeed, putative binding sites for AdcR protein have been found upstream of the $p h t A$, $p h t B$ and $p h t E$ genes, and of the lmb-phtD operon (Loisel et al., 2008; Panina et al., 2003). Binding of AdcR, induced under conditions of high $\mathrm{Zn}^{2+}$ concentration, inhibits the transcription of the genes under its dependence. Upon direct or indirect zinc starvation conditions, and hence a reduced intracellular concentration of this metal, repression by AdcR is relieved (Brenot et al., 2007; Claverys, 2001). However, and in contrast to what we have observed here, it was recently shown that the addition of zinc in culture medium elicits Pht production (Ogunniyi et al., 2009). Therefore, it is reasonable to estimate that production of Pht follows a bell-shaped curve within a given range of zinc concentrations. Also, the high zinc concentration effects observed by Ogunniyi et al. (2009), leading to increased Pht expression, may have little in vivo relevance as free zinc concentrations available in the human host are very low.

Dintilhac et al. (1997) concluded that, besides Psa, described as an ABC-type $\mathrm{Mn}^{2+}$ permease, and Adc, an ABC-type $\mathrm{Zn}^{2+}$ permease, a third transporter should exist, capable of transporting both $\mathrm{Zn}^{2+}$ and $\mathrm{Mn}^{2+}$. The Pht proteins or the laminin-binding protein would appear as candidates to fulfil this function. Our results are indicative of an additional role for the Pht isotypes. Indeed, the fact that wild-type and PhtD-deficient strains were able to grow in minimal medium in the absence of $\mathrm{Zn}^{2+}$ and $\mathrm{Mn}^{2+}$ is intriguing. In addition, the observation that growth of the quadruple mutant was rescued with a delay when $\mathrm{Zn}^{2+}$ or $\mathrm{Mn}^{2+}$ was added to the minimal medium is also of note. These observations could be explained if we consider that the Pht proteins act as $\mathrm{Zn}^{2+}$ and $\mathrm{Mn}^{2+}$ scavengers, with the function to store and concentrate these divalent cations. When wild-type and PhtD-deficient mutant strains were placed in minimal medium, they were able to start growing immediately as a result of the ions stored previously within the Pht proteins when the bacteria were in a richer medium. In contrast, the quadruple Pht mutants were not able to store these ions when placed in favourable conditions, and therefore could not grow when placed in poor medium. When $\mathrm{Zn}^{2+}$ or $\mathrm{Mn}^{2+}$ were added in excess to minimal medium, time was needed before the ions could be trapped by specific metal permeases or other metal transporters, because they had to 'find' them at random in the culture medium, without help from the Pht proteins. This might explain the delay needed for the quadruple Pht mutant to start growing under such conditions. Moreover, a possible scavenging and storage role for the Pht proteins is consistent with the presence of five to six cation-binding domains.

This speculative mechanism of storage, if confirmed, could also be considered as a means for the bacterium to regulate zinc and probably manganese homeostasis. Metal ions such as $\mathrm{Zn}^{2+}$ or $\mathrm{Mn}^{2+}$ are essential trace elements. However, they are potentially harmful to the bacterium when in excess (as observed when $1 \mathrm{mM} \mathrm{Zn}^{2+}$ was added to MS) because they may compete with other elements as cofactors for some critical enzymes. Therefore, it is essential for the bacteria to regulate metal homeostasis, and we suggest that the Pht family is involved in such regulation. Such a system would allow $S$. pneumoniae to survive when facing ion-restricted environments, for example during the initial stages of the colonization process in the human nasopharynx (Bunker et al., 1984; Harlyk et al., 1997).

The existence of polycistronic transcripts with $\mathrm{PhtD}$ might be explained by the requirement of $\mathrm{Zn}^{2+}$ or $\mathrm{Mn}^{2+}$ for $\mathrm{Lmb}$, an LraI family member, and YfnA to exert their function. In partial support of this, it has been suggested that $\mathrm{Mn}^{2+}$ is required for adhesion through the LraI family of proteins, a critical feature for virulence (Dintilhac \& Claverys, 1997; Papp-Wallace \& Maguire, 2006). In addition, it has been demonstrated in other contexts that laminin binds $\mathrm{Zn}^{2+}$ to promote high-affinity binding between laminin and laminin-binding proteins (Ancsin \& Kisilevsky, 1996; Bandyopadhyay et al., 2002). Therefore, we may hypothesize that $\mathrm{Lmb}$ needs $\mathrm{PhtD}$ to ensure the presence of $\mathrm{Zn}^{2+}$ when $\mathrm{Lmb}$ encounters laminin, which enhances binding to the host tissues. The close link between zinc and the Pht proteins may also explain why these proteins have been associated with the inhibition of C3b (Hostetter, 1999; Ogunniyi et al., 2009). Indeed, the cleavage of C3b by factor I in the presence of factor $\mathrm{H}$ is regulated by zinc (Blom et al., 2003). By controlling zinc concentration in the bacterial environment, the Pht isotypes might thus contribute to $\mathrm{C} 3 \mathrm{~b}$ inhibition in some circumstances, which needs to be investigated further.

In a vaccine context, by targeting the Pht protein family, the immune system may impede the bacteria in storing and using critical ions necessary for the invasion process. Consequently, our results confirm the Pht proteins as genuine vaccine candidates against pneumococcal infections. The different members of the Pht family have already been evaluated for their potential as pneumococcal vaccine antigens (Adamou et al., 2001; Godfroid et al., 2011; Hamel et al., 2004; Ogunniyi et al., 2007; Wizemann et al., 2001; Zhang et al., 2001). PhtA, PhtB and PhtD were examined for their ability to protect mice against a subset of pneumococcal isolates (Adamou et al., 2001). PhtD was found to afford the broadest protection, while PhtA 
immunization was efficient against a lesser number of the strains tested. This is in line with the results of the present study, where it is shown that PhtA is expressed in $62 \%$ of pneumococcal strains, and $\mathrm{PhtD}$ in $100 \%$. Although successfully used in two studies, the potential for PhtB to elicit cross-protection is not known as it was evaluated against a single strain only (Adamou et al., 2001; Zhang et al., 2001). However, as we found it in $81 \%$ of the strains, one may expect that its inter-strain coverage might not be optimal. PhtE is found in $97 \%$ of the strains, indicative of potential broad cross-protection. However, this Pht shares only $32 \%$ identity with the three other Pht isotypes, and its C-terminal part, the most immunogenic and conserved, is PhtE-specific. The region of PhtE common with the other Pht isotypes is not accessible to antibodies (Adamou et al., 2001; Hamel et al., 2004). Therefore, PhtD, which is present in all strains tested, has a highly conserved amino acid sequence among pneumococci and also demonstrates cross-reactivity with PhtA and $\mathrm{PhtB}$, represents the most suitable candidate amongst the Pht proteins for incorporation into pneumococcal vaccines.

\section{ACKNOWLEDGEMENTS}

The study was sponsored by GlaxoSmithKline Biologicals. We wish to thank Sylvie Vanderschrick, Hermenegildo Fernandez-Lopez, Régine Masengo Kalibiona, Isabelle Pinault, Julie Sansfaçons and Nathalie Ramet for their excellent technical assistance. Special thanks to Josée Hamel for her contribution to the initiation and development of the project. We are also grateful to Pascal Cadot and Ulrike Krause for editorial assistance. S. R., C. N., E. D. P., L. T., M.-C. M., C. F., D. M. and J. T. P. are employees of Glaxo SmithKline Biologicals.

\section{REFERENCES}

Adamou, J. E., Heinrichs, J. H., Erwin, A. L., Walsh, W., Gayle, T., Dormitzer, M., Dagan, R., Brewah, Y. A., Barren, P. \& other authors (2001). Identification and characterization of a novel family of pneumococcal proteins that are protective against sepsis. Infect Immun 69, 949-958.

Ajdić, D., McShan, W. M., McLaughlin, R. E., Savic, G., Chang, J., Carson, M. B., Primeaux, C., Tian, R., Kenton, S. \& other authors (2002). Genome sequence of Streptococcus mutans UA159, a cariogenic dental pathogen. Proc Natl Acad Sci U S A 99, 14434-14439.

Ancsin, J. B. \& Kisilevsky, R. (1996). Laminin interactions important for basement membrane assembly are promoted by zinc and implicate laminin zinc finger-like sequences. J Biol Chem 271, 6845-6851.

Bandyopadhyay, K., Karmakar, S., Ghosh, A. \& Das, P. K. (2002). High affinity binding between laminin and laminin binding protein of Leishmania is stimulated by zinc and may involve laminin zinc-finger like sequences. Eur J Biochem 269, 1622-1629.

Beghetto, E., Gargano, N., Ricci, S., Garufi, G., Peppoloni, S., Montagnani, F., Oggioni, M., Pozzi, G. \& Felici, F. (2006). Discovery of novel Streptococcus pneumoniae antigens by screening a wholegenome $\lambda$-display library. FEMS Microbiol Lett 262, 14-21.

Blom, A. M., Kask, L., Ramesh, B. \& Hillarp, A. (2003). Effects of zinc on factor I cofactor activity of C4b-binding protein and factor $\mathrm{H}$. Arch Biochem Biophys 418, 108-118.
Brendel, V. \& Trifonov, E. N. (1984). A computer algorithm for testing potential prokaryotic terminators. Nucleic Acids Res 12, 4411-4427.

Brenot, A., Weston, B. F. \& Caparon, M. G. (2007). A PerR-regulated metal transporter (PmtA) is an interface between oxidative stress and metal homeostasis in Streptococcus pyogenes. Mol Microbiol 63, 11851196.

Bridy-Pappas, A. E., Margolis, M. B., Center, K. J. \& Isaacman, D. J. (2005). Streptococcus pneumoniae: description of the pathogen, disease epidemiology, treatment, and prevention. Pharmacotherapy 25, 11931212.

Bunker, V. W., Hinks, L. J., Lawson, M. S. \& Clayton, B. E. (1984). Assessment of zinc and copper status of healthy elderly people using metabolic balance studies and measurement of leucocyte concentrations. Am J Clin Nutr 40, 1096-1102.

Claverys, J.-P. (2001). A new family of high-affinity ABC manganese and zinc permeases. Res Microbiol 152, 231-243.

Cockayne, A., Hill, P. J., Powell, N. B. L., Bishop, K., Sims, C. \& Williams, P. (1998). Molecular cloning of a 32-kilodalton lipoprotein component of a novel iron-regulated Staphylococcus epidermidis ABC transporter. Infect Immun 66, 3767-3774.

Dagan, R., Engelhard, D., Piccard, E. \& Englehard, D. (1992). Epidemiology of invasive childhood pneumococcal infections in Israel. The Israeli Pediatric Bacteremia and Meningitis Group. JAMA 268, 3328-3332.

Dagan, R., Käyhty, H., Wuorimaa, T., Yaich, M., Bailleux, F., Zamir, O. \& Eskola, J. (2004). Tolerability and immunogenicity of an eleven valent mixed carrier Streptococcus pneumoniae capsular polysaccharide-diphtheria toxoid or tetanus protein conjugate vaccine in Finnish and Israeli infants. Pediatr Infect Dis J 23, 91-98.

Dintilhac, A. \& Claverys, J.-P. (1997). The adc locus, which affects competence for genetic transformation in Streptococcus pneumoniae, encodes an $\mathrm{ABC}$ transporter with a putative lipoprotein homologous to a family of streptococcal adhesins. Res Microbiol 148, 119-131.

Dintilhac, A., Alloing, G., Granadel, C. \& Claverys, J.-P. (1997). Competence and virulence of Streptococcus pneumoniae: Adc and $\mathrm{PsaA}$ mutants exhibit a requirement for $\mathrm{Zn}$ and $\mathrm{Mn}$ resulting from inactivation of putative ABC metal permeases. Mol Microbiol 25, 727739.

Elsner, A., Kreikemeyer, B., Braun-Kiewnick, A., Spellerberg, B., Buttaro, B. A. \& Podbielski, A. (2002). Involvement of Lsp, a member of the LraI-lipoprotein family in Streptococcus pyogenes, in eukaryotic cell adhesion and internalization. Infect Immun 70, 4859-4869.

Fedson, D. C. \& Musher, D. M. (2004). Pneumococcal polysaccharide vaccines. In Vaccines, 4th edn, pp. 529-588. Edited by S. A. Plotkin \& W. A. Orenstein. Philadelphia, PA: Elsevier, Inc.

Ferretti, J. J., McShan, W. M., Ajdić, D., Savic, D. J., Savic, G., Lyon, K., Primeaux, C., Sezate, S., Suvorov, A. N. \& other authors (2001). Complete genome sequence of an M1 strain of Streptococcus pyogenes. Proc Natl Acad Sci U S A 98, 4658-4663.

Gagnon, G., Vadeboncoeur, C., Levesque, R. C. \& Frenette, M. (1992). Cloning, sequencing and expression in Escherichia coli of the ptsI gene encoding enzyme I of the phosphoenolpyruvate:sugar phosphotransferase transport system from Streptococcus salivarius. Gene 121, 71-78.

Godfroid, F., Hermand, P., Verlant, V., Denoël, P. \& Poolman, J. T. (2011). Preclinical evaluation of the Pht proteins as potential crossprotective pneumococcal vaccine antigens. Infect Immun 79, 238245.

Hamel, J., Charland, N., Pineau, I., Ouellet, C., Rioux, S., Martin, D. \& Brodeur, B. R. (2004). Prevention of pneumococcal disease in mice immunized with conserved surface-accessible proteins. Infect Immun 72, 2659-2670. 
Hanahan, D. (1985). Plasmid transformation by Simanis. In DNA Cloning, pp. 109-135. Edited by D. M. Glover. London: IRL Press.

Harlyk, C., Mccourt, J., Bordin, G., Rodriguez, A. R. \& van der Eeckhout, A. (1997). Determination of copper, zinc and iron in broncho-alveolar lavages by atomic absorption spectroscopy. J Trace Elem Med Biol 11, 137-142.

Hausdorff, W. P., Feikin, D. R. \& Klugman, K. P. (2005). Epidemiological differences among pneumococcal serotypes. Lancet Infect Dis 5, 83-93.

Hava, D. L. \& Camilli, A. (2002). Large-scale identification of serotype 4 Streptococcus pneumoniae virulence factors. Mol Microbiol 45, 13891406.

Hoskins, J., Alborn, W. E., Jr, Arnold, J., Blaszczak, L. C., Burgett, S., DeHoff, B. S., Estrem, S. T., Fritz, L., Fu, D.-J. \& other authors (2001). Genome of the bacterium Streptococcus pneumoniae strain R6. J Bacteriol 183, 5709-5717.

Hostetter, M. K. (1999). Opsonic and nonopsonic interactions of C3 with Streptococcus pneumoniae. Microb Drug Resist 5, 85-89.

Jenkinson, H. F. (1994). Cell surface protein receptors in oral streptococci. FEMS Microbiol Lett 121, 133-140.

Kunst, F., Ogasawara, N., Moszer, I., Albertini, A. M., Alloni, G., Azevedo, V., Bertero, M. G., Bessieres, P., Bolotin, A. \& other authors (1997). The complete genome sequence of the gram-positive bacterium Bacillus subtilis. Nature 390, 249-256.

Laemmli, U. K. (1970). Cleavage of structural proteins during the assembly of the head of bacteriophage T4. Nature 227, 680-685.

Livak, K. J. \& Schmittgen, T. D. (2001). Analysis of relative gene expression data using real-time quantitative PCR and the $2^{-\Delta \Delta C T}$ method. Methods 25, 402-408.

Loisel, E., Jacquamet, L., Serre, L., Bauvois, C., Ferrer, J. L., Vernet, T., Di Guilmi, A. M. \& Durmort, C. (2008). AdcAII, a new pneumococcal Zn-binding protein homologous with $\mathrm{ABC}$ transporters: biochemical and structural analysis. J Mol Biol 381, 594-606.

Lynch, J. P., III \& Zhanel, G. G. (2005). Escalation of antimicrobial resistance among Streptococcus pneumoniae: implications for therapy. Semin Respir Crit Care Med 26, 575-616.

Maruvada, R., Prasadarao, N. V. \& Rubens, C. E. (2009). Acquisition of factor $\mathrm{H}$ by a novel surface protein on group B Streptococcus promotes complement degradation. FASEB J 23, 3967-3977.

Mbelle, N., Huebner, R. E., Wasas, A. D., Kimura, A., Chang, I. \& Klugman, K. P. (1999). Immunogenicity and impact on nasopharyngeal carriage of a nonavalent pneumococcal conjugate vaccine. J Infect Dis 180, 1171-1176.

McCullers, J. A. \& Tuomanen, E. I. (2001). Molecular pathogenesis of pneumococcal pneumonia. Front Biosci 6, D877-D889.

Melin, M., Di Paolo, E., Tikkanen, L., Jarva, H., Neyt, C., Kayhty, H., Meri, S., Poolman, J. \& Vakevainen, M. (2010). Interaction of pneumococcal histidine triad proteins with human complement. Infect Immun 78, 2089-2098.

Morrison, D. A. \& Jaurin, B. (1990). Streptococcus pneumoniae possesses canonical Escherichia coli (sigma 70) promoters. Mol Microbiol 4, 1143-1152.

Nunes, S., Sá-Leão, R., Pereira, L. C. \& de Lencastre, H. (2008). Emergence of a serotype 1 Streptococcus pneumoniae lineage colonising healthy children in Portugal in the seven-valent conjugate vaccination era. Clin Microbiol Infect 14, 82-84.

Ogunniyi, A. D., Grabowicz, M., Briles, D. E., Cook, J. \& Paton, J. C. (2007). Development of a vaccine against invasive pneumococcal disease based on combinations of virulence proteins of Streptococcus pneumoniae. Infect Immun 75, 350-357.
Ogunniyi, A. D., Grabowicz, M., Mahdi, L. K., Cook, J., Gordon, D. L., Sadlon, T. A. \& Paton, J. C. (2009). Pneumococcal histidine triad proteins are regulated by the $\mathrm{Zn}^{2+}$-dependent repressor AdcR and inhibit complement deposition through the recruitment of complement factor H. FASEB J 23, 731-738.

Panina, E. M., Mironov, A. A. \& Gelfand, M. S. (2003). Comparative genomics of bacterial zinc regulons: enhanced ion transport, pathogenesis, and rearrangement of ribosomal proteins. Proc Natl Acad Sci U S A 100, 9912-9917.

Papp-Wallace, K. M. \& Maguire, M. E. (2006). Manganese transport and the role of manganese in virulence. Annu Rev Microbiol 60, 187-209.

Peterson, J. D., Umayam, L. A., Dickinson, T., Hickey, E. K. \& White, O. (2001). The comprehensive microbial resource. Nucleic Acids Res 29, 123-125.

Ranasinghe, C. \& Hobbs, A. A. (1998). A simple method to obtain the 5 ' ends of mRNA sequences by direct ligation of cDNA-RNA hybrids to a plasmid vector. Tech Tips Online 3, 128-132.

Riboldi-Tunnicliffe, A., Isaacs, N. W. \& Mitchell, T. J. (2005). $1.2 \AA$ crystal structure of the $S$. pneumoniae PhtA histidine triad domain a novel zinc binding fold. FEBS Lett 579, 5353-5360.

Rosenberg, M. \& Court, D. (1979). Regulatory sequences involved in the promotion and termination of RNA transcription. Annu Rev Genet 13, 319-353.

Sicard, A. M. (1964). A new synthetic medium for Diplococcus pneumoniae, and its use for the study of reciprocal transformations at the amiA locus. Genetics 50, 31-44.

Singleton, R. J., Hennessy, T. W., Bulkow, L. R., Hammitt, L. L., Zulz, T., Hurlburt, D. A., Butler, J. C., Rudolph, K. \& Parkinson, A. (2007). Invasive pneumococcal disease caused by nonvaccine serotypes among Alaska native children with high levels of 7 -valent pneumococcal conjugate vaccine coverage. JAMA 297, 1784-1792.

Smart, L. E., Dougall, A. J. \& Girdwood, R. W. A. (1987). New 23valent pneumococcal vaccine in relation to pneumococcal serotypes in systemic and non-systemic disease. J Infect 14, 209-215.

Spellerberg, B., Rozdzinski, E., Martin, S., Weber-Heynemann, J., Schnitzler, N., Lütticken, R. \& Podbielski, A. (1999). Lmb, a protein with similarities to the LraI adhesin family, mediates attachment of Streptococcus agalactiae to human laminin. Infect Immun 67, 871-878.

Tettelin, H., Nelson, K. E., Paulsen, I. T., Eisen, J. A., Read, T. D., Peterson, S., Heidelberg, J., DeBoy, R. T., Haft, D. H. \& other authors (2001). Complete genome sequence of a virulent isolate of Streptococcus pneumoniae. Science 293, 498-506.

Towbin, H., Staehelin, T. \& Gordon, J. (1979). Electrophoretic transfer of proteins from polyacrylamide gels to nitrocellulose sheets: procedure and some applications. Proc Natl Acad Sci U S A 76, 4350-4354.

Turner, D. H., Sugimoto, N. \& Freier, S. M. (1988). RNA structure prediction. Annu Rev Biophys Biophys Chem 17, 167-192.

Wizemann, T. M., Heinrichs, J. H., Adamou, J. E., Erwin, A. L., Kunsch, C., Choi, G. H., Barash, S. C., Rosen, C. A., Masure, H. R. \& other authors (2001). Use of a whole genome approach to identify vaccine molecules affording protection against Streptococcus pneumoniae infection. Infect Immun 69, 1593-1598.

Yamamoto, H., Uchiyama, S., Nugroho, F. A. \& Sekiguchi, J. (1997). A $23.4 \mathrm{~kb}$ segment at the $69^{\circ}-70^{\circ}$ region of the Bacillus subtilis genome. Microbiology 143, 1317-1320.

Zhang, Y., Masi, A. W., Barniak, V., Mountzouros, K., Hostetter, M. K. \& Green, B. A. (2001). Recombinant PhpA protein, a unique histidine motif-containing protein from Streptococcus pneumoniae, protects mice against intranasal pneumococcal challenge. Infect Immun 69, $3827-3836$.

Edited by: S. D. Bentley 